\title{
A Task-Specific Ionic-Liquid-Mediated Solvent-Free Protocol for Direct Access to Dimethyl Acetal Protected Benzimidazole 2-Carboxaldehydes
}

\author{
Barnali Deb ${ }^{a}$ \\ Ankita Chakraborty ${ }^{a}$ \\ Jewel Hossain ${ }^{\mathrm{b}}$ \\ Swapan Majumdar*a (i) \\ a Department of Chemistry, Tripura University, \\ Suryamaninagar, 799 022, India \\ smajumdar@tripurauniv.in \\ ${ }^{\mathrm{b}}$ Department of Chemistry, Ram Thakur College, Agartala 799 \\ 003, India
}

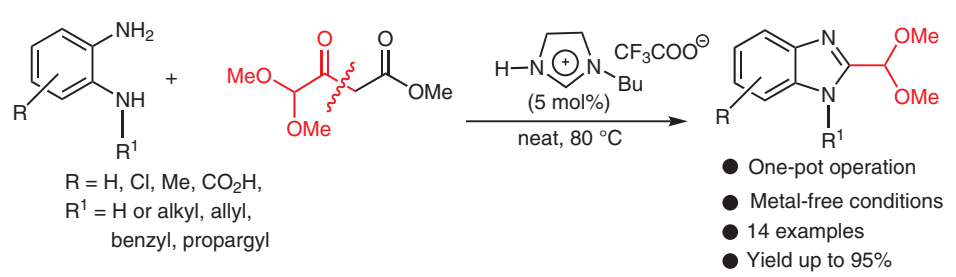

Received: 15.09 .2020

Accepted after revision: 30.09 .2020

Published online: 26.10 .2020

DOI: 10.1055/s-0040-1706391; Art ID: so-2020-d0032-psp

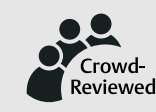

License terms: cc)

(c) 2020. The Author(s). This is an open access article published by Thieme under the terms of the Creative Commons Attribution-NonDerivative-NonCommercial-License, permitting copying and reproduction so long as the original work is given appropriate credit. Contents may not be used for commercial purposes or adapted, remixed, transformed or built upon. (https://creativecommons.org/licenses/by-nc-nd/4.0/)

Abstract A robust and straightforward protocol has been developed for the synthesis of a diverse array of dimethyl acetal protected benzimidazole-2-carboxaldehydes by reacting various 2 -amino aniline derivatives with methyl 4,4-dimethoxy-3-oxobutanoate using the taskspecific imidazolium ionic liquid (HBIm.TFA) as a promoter for $\mathrm{N}-\mathrm{C} / \mathrm{C}-\mathrm{N}$ annulation processes. The present protocol offers several advantages over existing protocols, such as single-step process, short reaction times, very mild reaction conditions, high yields, ease of purification, recovery and reusability of the catalyst, and scale-up of the reaction.

Key words benzimidazole carboxaldehydes, dimethyl acetal, C-C bond cleavage, task-specific ionic liquid

In drug discovery programs and for identifying biological leads, nitrogen-containing fused heterocyclic molecules play an important role as molecular templates. Among them, benzimidazole-containing heterocycles are of importance because of their broad spectrum of biological and therapeutic potentialities, ${ }^{1}$ making them one of the more widely investigated heterocyclic scaffolds. In addition to their biological potential, they are important intermediates in many synthetic organic and inorganic reactions, ${ }^{2}$ in dye and polymer synthesis, ${ }^{3}$ in fluorescence, ${ }^{4}$ chemosensing, ${ }^{5}$ crystal engineering, ${ }^{6}$ and corrosion science. ${ }^{7}$ They also act as ligands in the synthesis of transition-metal complexes of structural and biological interest. ${ }^{8}$ Therefore, their synthesis has received considerable attention and this has led to the development of several methods for the synthesis of benzimidazoles. These include the condensation of aromatic 1,2-diamines with carboxylic acids or their derivatives, generally under harsh conditions, ${ }^{3,9}$ oxidative cyclocondensation ${ }^{10}$ with aldehydes, or copper(I) catalysed coupling of 0 -haloacetanilides with amines or amidines, ${ }^{11}$ while very recently we and others also developed a benzimidazole synthesis by reaction with 1,2-diaminobenzene derivatives with active methylene compounds using a range of activators. ${ }^{12-14}$ In addition to these methods, rearrangement of quinoxalines or quinoxalone derivatives under different conditions to form benzimidazole derivatives have been documented. ${ }^{14}$ Derivatives of benzimidazole-2-carboxaldehyde have found applications in diverse therapeutic areas, ${ }^{15}$ as well as in chalcone preparation, ${ }^{16}$ generation of Schiff's bases, ${ }^{17}$ and for the creation of a library of fused polyheterocycles. ${ }^{18}$ Unfortunately no straightforward synthesis of functionalized benzimidazole-2-carboxaldehydes has been reported to date. They can be synthesized via multistep pathways (such as pathways 1-5 in Scheme 1): (1) condensation of $o$-phenylenediamine with tartaric acid followed by cleavage of the diol with $\mathrm{NaIO}_{4} ;{ }^{18 \mathrm{~d}, \mathrm{e}}$ (2) condensation of 1,2-diaminobenzene with glycolic acid and then oxidation with $\mathrm{MnO}_{2} ;{ }^{19}$ (3) oxidation of 2-methyl benzimidazole with $\mathrm{SeO}_{2} ;{ }^{20}(4)$ direct and/or directed lithiation at the 2-position of benzimidazole followed by trapping with DMF;21 and (5) condensation of 1,2-diamino enzene with ethyl diethyoxyacetate in $\mathrm{Na} / \mathrm{EtOH}$ followed by hydrolytic cleavage. ${ }^{22}$ 


$$
\begin{array}{ll}
\text { i) } \mathrm{Glycolic} \mathrm{acid} \\
6 \mathrm{M} \mathrm{HCl} \text {, reflux } \\
\text { ii) } \mathrm{MnO}_{2}
\end{array} \begin{aligned}
& \text { i) } \mathrm{Acetic} \mathrm{acid} \\
& \text { reflux }
\end{aligned}
$$

Scheme 1 General strategies involved in the synthesis of benzimidazole 2-carboxaldehydes

However, despite some notable advantages of the reported methods for the synthesis of benzimidazoles and benzimidazole 2-carboxaldehydes they generally suffer from a range of drawbacks, such as the requirement for stoichiometric or excess amounts of strong oxidants, high temperatures, transition-metal catalysts or harsh reaction conditions. In the area of organic synthesis, $\mathrm{C}-\mathrm{C}$ bondcleavage reaction is a topic of interest that allows $\mathrm{C}-\mathrm{C} / \mathrm{C}-\mathrm{N}$ bond annulation to be used to construct new molecules of interest. ${ }^{23}$ In spite of significant advances in this field, most methods rely on transition-metal catalysis. In recent times, much attention has been focused on organic reactions promoted by ionic liquids.

As a part of our ongoing program to explore the potential of protic ionic liquids in the activation of various functional groups and subsequent organic transformations, we have already demonstrated their efficacy as bifunctional catalysts for Boc protection-deprotection of amines, cleavage of 1,3-dioxolanes and in grinding chemistry. ${ }^{10 a, 24}$ Herein, we wish to report a strategy for the direct synthesis of dimethyl acetal protected benzimidazole 2-carboxaldehydes using methyl 4,4-dimethoxy-3-oxobutanoate in the presence of 1-butyl imidazolium trifluoroacetate (HBIm·TFA) as a bifunctional catalyst (Scheme 2).

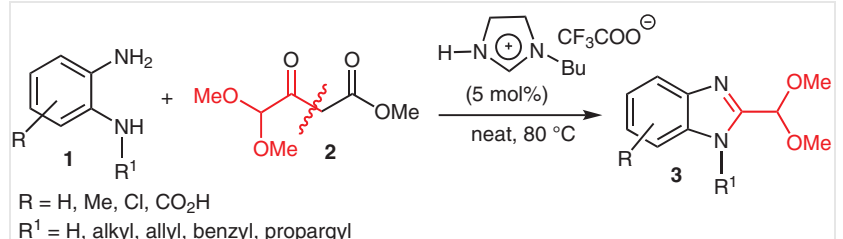

Scheme 2 Protic ionic liquid promoted synthesis of benzimidazole 2-carboxaldehyde dimethylacetals
To optimize the reaction conditions, 0 -phenylenediamine (1a) and methyl 4,4-dimethoxy-3-oxobutanoate (2) were chosen for the model reaction under different reaction conditions. Previously we have reported ${ }^{12 a}$ that the neutral ionic liquid [BMIm]Br or basic ionic liquid [BMIm]OH ( $10 \mathrm{~mol} \%$ ) could be utilised as activators for the synthesis of benzimidazoles by reaction of $\boldsymbol{o}$-phenylenediamines with $\beta$-keto esters or amides at $115-120{ }^{\circ} \mathrm{C}$, with the reaction proceeding through formation of a seven-membered benzodiazepinone intermediate. Unfortunately our initial attempts with these ionic liquid activators failed to produce the desired product in satisfactory yield on heating 1a with 2 at $80{ }^{\circ} \mathrm{C}$ for 4 or 12 hours, respectively (Table 1 , entries 1 and 2 ), and further increasing the temperature did not improve the yield, probably due to decomposition of $\mathbf{2}$. However, heating the reaction mixture at $80^{\circ} \mathrm{C}$ in the presence of $5 \mathrm{~mol} \%$ of protic ionic liquid (HBIm.TFA) for $15 \mathrm{~min}$ produced the desired benzimidazole 2-carboxldehyde dimethyl acetal 3a in 95\% yield (entry 3), although reactions at room temperature or without catalyst were not successful (entries 4 and 5). The appearance of two singlets at $\delta=5.70$ ppm $(1 \mathrm{H})$ and $3.46 \mathrm{ppm}(6 \mathrm{H})$ in the ${ }^{1} \mathrm{H}$ NMR spectrum and at $\delta=98.4$ and $53.6 \mathrm{ppm}$ in the ${ }^{13} \mathrm{C}$ NMR spectra of 3a corroborated the presence of the dimethyl acetal group (see

\begin{tabular}{|c|c|c|c|c|}
\hline Entry & Activator & Temp $\left({ }^{\circ} \mathrm{C}\right)$ & Time & Yield (\%) \\
\hline 1 & {$[\mathrm{BMIm}] \mathrm{Br}^{\mathrm{b}}$} & 80 & $4 \mathrm{~h}$ & 50 \\
\hline 2 & {$[\mathrm{BMIm}] \mathrm{OH}^{\mathrm{b}}$} & 80 & $12 \mathrm{~h}$ & 20 \\
\hline 3 & {$[\mathrm{HBIm}][\mathrm{TFA}]^{\mathrm{b}}$} & 80 & $15 \min$ & 95 \\
\hline 4 & {$[\mathrm{HBIm}][\mathrm{TFA}]^{\mathrm{b}}$} & $\mathrm{rt}$ & $2 \mathrm{~h}$ & NR \\
\hline 5 & none & 80 & $2 \mathrm{~h}$ & NR \\
\hline 6 & {$\left[\mathrm{Et}_{3} \mathrm{NH}\right][\mathrm{TFA}]^{\mathrm{b}}$} & 80 & $2 \mathrm{~h}$ & trace \\
\hline 7 & $\mathrm{SiO}_{2}-\mathrm{KHSO}_{4}$ & 80 & $2 \mathrm{~h}$ & 80 \\
\hline 8 & $\mathrm{SiO}_{2}-\mathrm{HClO}_{4}$ & 80 & $2 \mathrm{~h}$ & 80 \\
\hline 9 & $\mathrm{SiO}_{2}-\mathrm{H}_{2} \mathrm{SO}_{4}$ & 80 & $3 \mathrm{~h}$ & 82 \\
\hline 10 & $\mathrm{FeCl}_{3}-\mathrm{SiO}_{2}$ & 80 & $90 \mathrm{~min}$ & 87 \\
\hline 11 & Nano TS 1 & 80 & $50 \mathrm{~min}$ & 83 \\
\hline 12 & Amberlite IR120H ${ }^{+}$ & 80 & $2 \mathrm{~h}$ & 78 \\
\hline 13 & Amberlyst 15 & 80 & $90 \mathrm{~min}$ & 73 \\
\hline 14 & {$[\mathrm{HBIm}][\mathrm{TFA}]$} & 80 & $30 \mathrm{~min}$ & $92^{c}$ \\
\hline
\end{tabular}
Supporting Information). A molecular ion at $m / z 193$ further supported the structure of 3a. We also carried out the

Table 1 Screening of Catalysts for Optimisation of Reaction

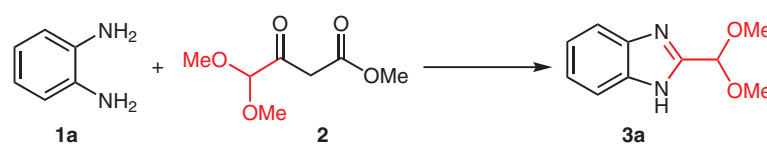

a Isolated yield on $1 \mathrm{mmol}$ scale.

b 5 mol\% was used.

c $10 \mathrm{mmol}$ scale. 
reaction with triethyl ammonium trifluoroacetate ([Et $\left.\left.{ }_{3} \mathrm{NH}\right][\mathrm{TFA}]\right)$, prepared from an equimolar mixture of triethylamine and trifluoroacetic acid under identical reaction conditions (entry 6 ) but no product was detected. We also screened some silica supported acidic reagents such as $\mathrm{SiO}_{2}-\mathrm{KHSO}_{4}$ (40 mg, 10\% $\mathrm{KHSO}_{4}$ ), ${ }^{25} \mathrm{SiO}_{2}-\mathrm{HClO}_{4}$ (40 mg, 10\% $\mathrm{w} / \mathrm{v}),{ }^{26} \mathrm{SiO}_{2}-\mathrm{H}_{2} \mathrm{SO}_{4}$ (40 mg, $\left.10 \% \mathrm{w} / \mathrm{v}\right),{ }^{27} \mathrm{SiO}_{2}-\mathrm{FeCl}_{3}$ (32 mg containing ca. $\left.10 \% \mathrm{FeCl}_{3}\right),{ }^{12 \mathrm{~b}, 28}$ and nano titania-silica (TS1). ${ }^{29}$ These supported reagents also afforded 2-(1,1-dimethoxy)methyl benzimidazole (3a) in 80, 80, 82, 87, and $83 \%$ yield, respectively (entries $7-11$ ). The reaction was also investigated using commercially available sulfonic acid resins Amberlyst-15 and Amberlite IR $120 \mathrm{H}^{+}$(entries 12 and 13). The resin-based catalysts resulted in lower yields compared to the silica supported reagents. No reaction was observed when the model reaction was conducted using 5 mol\% of neat trifluoroacetic acid (results not shown). These control experiments indicated that both a proton and imidazolium cation are essential to produce $\mathbf{3 a}$ in high yield.

From the results presented in Table 1 , the protic ionic liquid (HBImTFA) showed the best catalytic activity for the synthesis of 3a with respect to both reaction time and yield. The reaction could also be scaled up to $10 \mathrm{mmol}$ scale with very little decrease of the yield using the same mol\% of ionic liquid (entry 14). It is noteworthy that the high yield of 3a indicates its stability in the mildly acidic reaction medium. Another important feature of the present protocol is the recyclability of the ionic liquid for five cycles without significant loss of catalytic efficiency (95-88\%). Since most of the benzimidazole product solidified after completion of reaction, the product could be collected by filtration and the mother liquor containing the ionic liquid recycled after evaporation of solvent.

Having optimized the reaction conditions, the scope of the reaction with various 0 -phenylenediamines with methyl 4,4-dimethoxy-3-oxobutanoate was subsequently explored; the results are summarized in Figure 1. A wide range of aromatic diamines with electron-withdrawing or electron-donating groups at different positions of the aromatic ring, reacted smoothly in the presence of protic ionic liquid ([HBIm]TFA) to afford benzimidazole-2-carboxaldehyde dimethyl acetals $\mathbf{3 b}-\mathbf{e}$ and $\mathbf{3 g}-\mathbf{1}$ in good to excellent yields within two hours. In contrast, 4-nitro-1,2-diaminobenzene afforded a different type of benzimidazole by $\mathrm{C}-\mathrm{C}$ bond cleavage due to the presence of the strongly electronwithdrawing group in the aromatic ring depleting the negative charge on the nitrogen in intermediate $\mathbf{D}$ (see Scheme 3 below), with methoxy-directed oxidative cleavage resulting in 6-nitro- $1 H$-benzo[d]imidazole-2-yl acetate (3f) in 35\% yield with concomitant formation of many other unidentified products. All the synthesized products 3a-1 were characterized by spectroscopic analyses. Unfortunately, 2,3-diaminopyridine failed to give the corresponding pyridoimidazole derivative; rather, it produced the seven-membered heterocycle $\mathbf{3 m}$, as an inseparable mixture of tautomers, in $75 \%$ yield. A similar trend was observed in the case of 2aminothiophenol, which yielded benzothiazepinone $\mathbf{3 n}$ as the sole product. Attempted reaction of 2-aminophenol yielded a mixture of unidentified products, probably due to the lower nucleophilicity of the phenolic OH group, meaning that the cyclisation step is not favourable.

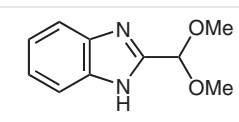

3a: $95 \%, 15 \mathrm{~min}$

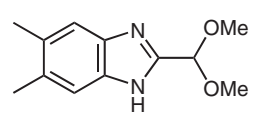

3c: $95 \%, 10 \mathrm{~min}$

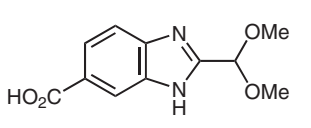

3e: $85 \%, 40 \mathrm{~min}$

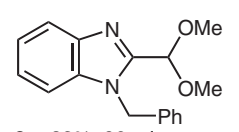

$3 g: 82 \%, 90 \mathrm{~min}$

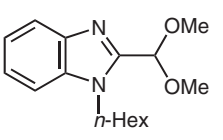

3i: $89 \%, 90 \mathrm{~min}$

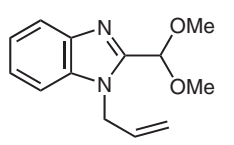

3k: $86 \%, 45 \mathrm{~min}$

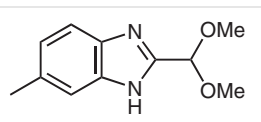

3b: $91 \%, 12 \min$
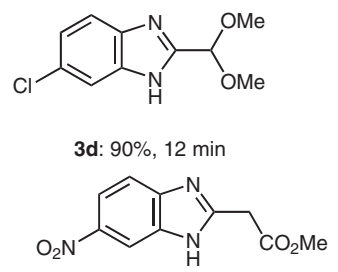

3f: $35 \%, 120 \mathrm{~min}$

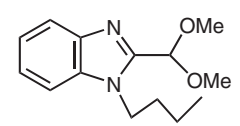

3h: $80 \%, 30 \mathrm{~min}$

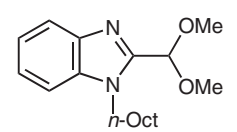

3j: $90 \%, 120$ min

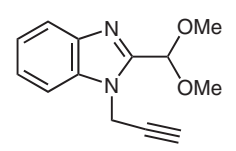

31: $92 \%, 80 \mathrm{~min}$
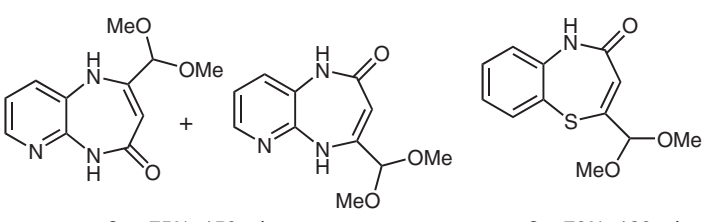

3n: $70 \%, 120 \mathrm{~min}$
Figure 1 o-Phenylenediamine scope

Considering the mechanism of the reaction, we anticipated that both the imidazolium cation and $\mathrm{N}-\mathrm{H}$ proton are indispensable for catalytic activity as neither the imidazolium cation (entries 1 and 2) nor proton alone (entries 6, 12 and 13) provide the optimum yield of product, but $N$-butyl imidazolium trifluoroacetate provided the best yield in the shortest reaction time. Thus, we speculate that dual activation of the ketone oxygen of the ketone and the oxygens of the acetal group of reagent $\mathbf{2}$ ( $\mathbf{A}$ in Scheme 3 ) by both the proton and imidazolium cation activates the ketone carbonyl, thereby making it more susceptible to nucleophilic attack by the amino group of the 0 -phenylenediamine. 


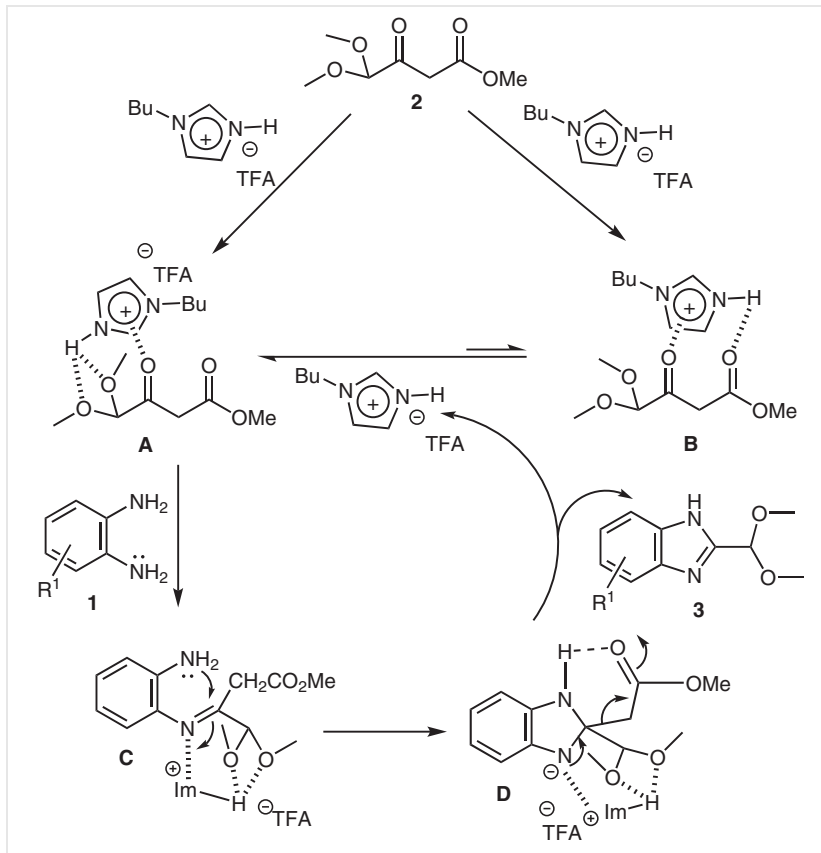

Scheme 3 Plausible mechanism for dual activation of $\mathbf{2}$ by [HBIm]TFA and catalytic cycle in the synthesis of acetal 3

The resulting imine $\mathbf{C}$ undergoes ring-closure onto the second amino group to form aminal $\mathbf{D}$ followed by hydrogen-bond-assisted $\mathrm{C}-\mathrm{C}$ bond cleavage to give the benzimidazole (Scheme 3). Although the possibility of simultaneous activation of both carbonyls of $\mathbf{2}$, leading to $\mathbf{B}$, cannot be overlooked; in such a situation, the benzodiazepinone may result from attack by the two amino groups on both activated carbonyls.

${ }^{1} \mathrm{H}$ and ${ }^{13} \mathrm{C}$ NMR spectra were recorded with a Bruker Ascend 400 spectrometer ( $400 \mathrm{MHz}$ for ${ }^{1} \mathrm{H}$ and $100 \mathrm{MHz}$ for ${ }^{13} \mathrm{C}$ ). Chemical shifts are reported in parts per million with tetramethylsilane internal reference, and coupling constants are reported in Hertz. Proton multiplicities are represented as s (singlet), d (doublet), dd (double doublet), $\mathrm{t}$ (triplet), q (quartet), and $\mathrm{m}$ (multiplet). Infrared spectra were recorded with a Fourier transform infrared (FT-IR, Model: Spectrum 100) spectrophotometer as $\mathrm{KBr}$ pellets or in thin films. The reported melting points are uncorrected. High-resolution mass spectrometric (HR-MS) data were acquired by electrospray ionization with a Q-ToFmicro quadrupole mass spectrometer.

All commercial reagents were used without further purification, unless otherwise specified. Ethyl acetate and petroleum ether $\left(60-80{ }^{\circ} \mathrm{C}\right)$ were distilled before use. Column chromatography was performed on silica gel (60-120 mesh, 0.12-0.25 mm). Analytical thin-layer chromatography was performed on $0.25 \mathrm{~mm}$ silica gel plates with a UV254 fluorescent indicator.

\section{General Procedure}

The requisite $o$-phenylenediamine $(108 \mathrm{mg}, 1 \mathrm{mmol}$ ) and methyl 4,4dimethoxy-3-oxobutanoate (194 mg, $1.1 \mathrm{mmol}$ ) were taken in a coneshaped $(10 \mathrm{~mL})$ flask equipped with a small magnetic bar. HBIm·TFA
(12 $\mathrm{mg}, 0.05 \mathrm{mmol}$ ) was then added to the mixture, which was heated at $80{ }^{\circ} \mathrm{C}$ without solvent until the disappearance of the 0 -phenylenediamine (TLC). After completion of reaction, the solid mass was washed several times with water to remove the ionic liquid catalyst. Finally, the product was purified by crystallization using ethyl acetate-hexane, and ionic liquid was recovered from the mother liquor. In some cases, the product was purified by column chromatography over silica gel, eluting with $10-50 \%$ ethyl acetate in hexane.

\section{2-(Dimethoxymethyl)-1H-benzimidazole (3a)}

Yield: $182 \mathrm{mg}$ (95\%); colourless solid; $\mathrm{mp} 180^{\circ} \mathrm{C}$.

IR (neat): 2824, 1423, 1329, 1116, $1066 \mathrm{~cm}^{-1}$.

${ }^{1} \mathrm{H}$ NMR $\left(400 \mathrm{MHz}, \mathrm{CDCl}_{3}\right): \delta=7.66-7.64(\mathrm{dd}, J=5.6,3.2 \mathrm{~Hz}, 2 \mathrm{H}$ ), 7.30-7.28 (dd, $J=6.0,3.2 \mathrm{~Hz}, 2 \mathrm{H}), 5.70(\mathrm{~s}, 1 \mathrm{H}), 3.46$ (s, $6 \mathrm{H})$.

${ }^{13} \mathrm{C}$ NMR $\left(100 \mathrm{MHz}, \mathrm{CDCl}_{3}\right): \delta=150.3,137.9,122.9,115.6,98.4,53.6$.

HRMS (ESI-TOF): $m / z[\mathrm{M}+\mathrm{H}]^{+}$calcd for $\mathrm{C}_{10} \mathrm{H}_{12} \mathrm{~N}_{2} \mathrm{O}_{2}$ : 193.0977; found: 193.0959 .

\section{2-(Dimethoxymethyl)-6-methyl-1H-benzimidazole (3b)}

Yield: $187 \mathrm{mg}$ (91\%); thick liquid.

IR (neat): 2927, 2828, 1692, 1442, 1325, 1107, $1055 \mathrm{~cm}^{-1}$.

${ }^{1} \mathrm{H}$ NMR $\left(400 \mathrm{MHz}, \mathrm{CDCl}_{3}\right): \delta=7.53(\mathrm{~d}, J=8 \mathrm{~Hz}, 1 \mathrm{H}), 7.40(\mathrm{~s}, 1 \mathrm{H}), 7.10$ (d, J = 7.6 Hz, $1 \mathrm{H}), 5.67(\mathrm{~s}, 1 \mathrm{H}), 3.44(\mathrm{~s}, 6 \mathrm{H}), 2.47(\mathrm{~s}, 3 \mathrm{H})$.

${ }^{13} \mathrm{C}$ NMR (100 MHz, $\left.\mathrm{CDCl}_{3}\right): \delta=150.0,132.8,124.4,115.2,98.5,53.5$, 21.6.

HRMS (ESI-TOF): $m / z[\mathrm{M}+\mathrm{H}]^{+}$calcd for $\mathrm{C}_{11} \mathrm{H}_{14} \mathrm{~N}_{2} \mathrm{O}_{2}$ : 207.1134; found: 207.1011.

\section{2-(Dimethoxymethyl)-5,6-dimethyl-1H-benzimidazole (3c)}

Yield: $209 \mathrm{mg}$ (95\%); colourless solid; mp $100{ }^{\circ} \mathrm{C}$.

IR (neat): 2926, 1691, 1516, 1449, 1192, $1062 \mathrm{~cm}^{-1}$.

${ }^{1} \mathrm{H} \mathrm{NMR}\left(400 \mathrm{MHz}, \mathrm{CDCl}_{3}\right): \delta=7.39(\mathrm{~s}, 2 \mathrm{H}), 5.66(\mathrm{~s}, 1 \mathrm{H}), 3.43(\mathrm{~s}, 6 \mathrm{H})$, $2.36(\mathrm{~s}, 6 \mathrm{H})$.

${ }^{13} \mathrm{C}$ NMR $\left(100 \mathrm{MHz}, \mathrm{CDCl}_{3}\right): \delta=149.4,131.9,115.7,98.6,77.0,53.5$, 20.3 .

HRMS (ESI-TOF): $m / z$ [M+H] $]^{+}$calcd for $\mathrm{C}_{12} \mathrm{H}_{16} \mathrm{~N}_{2} \mathrm{O}_{2}$ : 221.1290; found: 221.1250 .

\section{6-Chloro-2-(dimethoxymethyl)-1H-benzimidazole (3d)}

Yield: $203 \mathrm{mg}$ (90\%); colourless solid; $\mathrm{mp} 140{ }^{\circ} \mathrm{C}$.

IR (neat): 2920, 1421, 1321, 1105, $1055 \mathrm{~cm}^{-1}$.

${ }^{1} \mathrm{H} \mathrm{NMR}\left(400 \mathrm{MHz}, \mathrm{CDCl}_{3}\right): \delta=7.63(\mathrm{~s}, 1 \mathrm{H}), 7.55(\mathrm{~s}, 1 \mathrm{H}), 7.25(\mathrm{~s}, 1 \mathrm{H})$, $5.66(\mathrm{~s}, 1 \mathrm{H}), 3.46(\mathrm{~s}, 6 \mathrm{H})$.

${ }^{13} \mathrm{C}$ NMR $\left(100 \mathrm{MHz}, \mathrm{CDCl}_{3}\right): \delta=151.3,128.6,123.6,98.3,77.0,53.7$.

HRMS (ESI-TOF): $m / z[\mathrm{M}+\mathrm{H}]^{+}$calcd for $\mathrm{C}_{10} \mathrm{H}_{11} \mathrm{ClN}_{2} \mathrm{O}_{2}: 227.0587$; found: 227.0561 .

\section{2-(Dimethoxymethyl)-1H-benzimidazole-5-carboxylic Acid (3e)}

Yield: $200 \mathrm{mg}$ (85\%); yellowish solid; $\mathrm{mp} 70{ }^{\circ} \mathrm{C}$.

IR (neat): 2938, 2835, 1679, 1417, 1191, $1055 \mathrm{~cm}^{-1}$.

${ }^{1} \mathrm{H}$ NMR $\left(400 \mathrm{MHz}\right.$, DMSO- $\left.d_{6}\right): \delta=12.87(\mathrm{~s}, 1 \mathrm{H}), 12.74(\mathrm{~s}, 1 \mathrm{H}), 8.21(\mathrm{~s}$, $0.5 \mathrm{H}), 8.08(\mathrm{~s}, 0.5 \mathrm{H}), 7.82(\mathrm{~s}, 1 \mathrm{H}), 7.67(\mathrm{~s}, 0.5 \mathrm{H}), 7.52(\mathrm{~s}, 0.5 \mathrm{H}), 5.65$ (s, $1 \mathrm{H}), 3.38(\mathrm{~s}, 6 \mathrm{H})$. 
${ }^{13} \mathrm{C}$ NMR (100 MHz, DMSO- $\left.d_{6}\right): \delta$ (two tautomers) $=168.2,153.8$, $152.9,146.4,142.7,137.6,133.9,125.4,124.7,124.4,123.1,121.5$, 119.2, 114.1, 112.0, 98.9, 55.1, 53.9.

HRMS (ESI-TOF): $m / z$ [M + H] $]^{+}$calcd for $\mathrm{C}_{11} \mathrm{H}_{12} \mathrm{~N}_{2} \mathrm{O}_{4}$ : 237.0875; found: 237.0838 .

\section{Methyl 2-(6-Nitro-1H-benzo[d]imidazole-2-yl)acetate (3f)}

Yield: $83 \mathrm{mg}$ (35\%); orange solid; $\mathrm{mp} 130{ }^{\circ} \mathrm{C}$.

IR (neat): 2944, 1726, 1520, 1339, 1223, $1012 \mathrm{~cm}^{-1}$.

${ }^{1} \mathrm{H}$ NMR (400 MHz, DMSO- $d_{6}$ ): $\delta=13.09$ (bs, $1 \mathrm{H}$ ), 8.45 (s, $1 \mathrm{H}$ ), 8.10 (bs, $1 \mathrm{H}), 7.71$ (bs, $1 \mathrm{H}), 4.11$ (s, $2 \mathrm{H}), 3.70$ (s, $3 \mathrm{H})$.

${ }^{13} \mathrm{C}$ NMR $\left(100 \mathrm{MHz}\right.$, DMSO- $\left.d_{6}\right): \delta=169.2,152.8,142.9,139.6,118.4$, $115.1,112.2,108.6,52.7,35.5$.

HRMS (ESI-TOF): $m / z[\mathrm{M}+\mathrm{H}]^{+}$calcd for $\mathrm{C}_{10} \mathrm{H}_{9} \mathrm{~N}_{3} \mathrm{O}_{4}: 236.0671$; found: 236.0830 .

\section{1-Benzyl-2-(dimethoxymethyl)-1H-benzimidazole (3g)}

Yield: $231 \mathrm{mg}$ (82\%); thick liquid.

IR (neat): 2938, 2832, 1607, 1457, 1334, 1198, $1062 \mathrm{~cm}^{-1}$.

${ }^{1} \mathrm{H} \mathrm{NMR}\left(400 \mathrm{MHz}, \mathrm{CDCl}_{3}\right): \delta=7.83(\mathrm{~d}, J=7.6 \mathrm{~Hz}, 1 \mathrm{H}), 7.31-7.15(\mathrm{~m}, 6$ $\mathrm{H}), 7.14(\mathrm{~d}, J=6.4 \mathrm{~Hz}, 2 \mathrm{H}), 5.58(\mathrm{~s}, 3 \mathrm{H}), 3.45(\mathrm{~s}, 6 \mathrm{H})$.

${ }^{13} \mathrm{C}$ NMR $\left(100 \mathrm{MHz}, \mathrm{CDCl}_{3}\right): \delta=149.6,141.9,136.3,135.7,128.5$, 127.4, 126.5, 123.3, 122.2, 120.3, 110.4, 100.6, 54.6, 47.6.

HRMS (ESI-TOF): $m / z[\mathrm{M}+\mathrm{H}]^{+}$calcd for $\mathrm{C}_{17} \mathrm{H}_{18} \mathrm{~N}_{2} \mathrm{O}_{2}: 283.1447$; found: 283.1429.

\section{1-Butyl-2-(dimethoxymethyl)-1H-benzimidazole (3h)}

Yield: $198 \mathrm{mg}$ (80\%); thick liquid.

IR (neat): 2956, 1462, 1421, 1334, 1203, $1063 \mathrm{~cm}^{-1}$.

${ }^{1} \mathrm{H}$ NMR $\left(400 \mathrm{MHz}, \mathrm{CDCl}_{3}\right): \delta=7.79(\mathrm{~d}, J=7.2 \mathrm{~Hz}, 1 \mathrm{H}), 7.39(\mathrm{~d}, J=7.2$ $\mathrm{Hz}, 1 \mathrm{H}), 7.32-7.24(\mathrm{~m}, 2 \mathrm{H}), 5.60(\mathrm{~s}, 1 \mathrm{H}), 4.30(\mathrm{t}, J=8 \mathrm{~Hz}, 2 \mathrm{H}), 3.47$ (s, $6 \mathrm{H}), 1.86-1.79(\mathrm{~m}, 2 \mathrm{H}), 1.47-1.38(\mathrm{~m}, 2 \mathrm{H}), 0.98(\mathrm{t}, J=7.2 \mathrm{~Hz}, 3 \mathrm{H})$.

${ }^{13} \mathrm{C}$ NMR $\left(100 \mathrm{MHz}, \mathrm{CDCl}_{3}\right): \delta=149.2,141.9,135.6,123.1,122.1$, $120.3,110.0,100.5,54.7,44.1,31.7,20.2,13.8$.

HRMS (ESI-TOF): $m / z[\mathrm{M}+\mathrm{H}]^{+}$calcd for $\mathrm{C}_{14} \mathrm{H}_{20} \mathrm{~N}_{2} \mathrm{O}_{2}$ : 249.1603; found: 249.1589 .

\section{1-Hexyl-2-(dimethoxymethyl)-1H-benzimidazole (3i)}

Yield: $246 \mathrm{mg}$ (89\%); yellowish sticky solid.

IR (neat): 2929, 1462, 1421, 1334, 1203, $1063 \mathrm{~cm}^{-1}$.

${ }^{1} \mathrm{H} \mathrm{NMR}\left(400 \mathrm{MHz}, \mathrm{CDCl}_{3}\right): \delta=7.79(\mathrm{dd}, J=11.6,2.0 \mathrm{~Hz}, 1 \mathrm{H}), 7.39$ (dd, $J=5.7,2.0 \mathrm{~Hz}, 1 \mathrm{H}), 7.32-7.24(\mathrm{~m}, 2 \mathrm{H}), 5.59(\mathrm{~s}, 1 \mathrm{H}), 4.30(\mathrm{t}, J=7.6 \mathrm{~Hz}$, $2 \mathrm{H}), 3.48(\mathrm{~s}, 3 \mathrm{H}), 1.88-1.80(\mathrm{~m}, 2 \mathrm{H}), 1.41-1.32(\mathrm{~m}, 6 \mathrm{H}), 0.90(\mathrm{t}, J=$ $7.2 \mathrm{~Hz}, 3 \mathrm{H})$.

${ }^{13} \mathrm{C}$ NMR $\left(100 \mathrm{MHz}\right.$, DMSO- $\left.d_{6}\right): \delta=149.2,142.0,135.6,123.1,122.1$, $120.4,110.0,100.7,54.7,44.3,31.4,29.6,22.5,14.0$.

HRMS (ESI-TOF): $m / z[\mathrm{M}+\mathrm{H}]^{+}$calcd for $\mathrm{C}_{16} \mathrm{H}_{24} \mathrm{~N}_{2} \mathrm{O}_{2}: 277.1916$; found: 277.1789 .

\section{1-Octyl-2-(dimethoxymethyl)-1H-benzimidazole (3j)}

Yield: $275 \mathrm{mg}$ (90\%); yellowish sticky solid.

IR (neat): 2925, 1461, 1336, 1201, 1066, $965 \mathrm{~cm}^{-1}$.
${ }^{1} \mathrm{H} \mathrm{NMR}\left(400 \mathrm{MHz}, \mathrm{CDCl}_{3}\right): \delta=7.80(\mathrm{t}, J=6.8 \mathrm{~Hz}, 1 \mathrm{H}), 7.40(\mathrm{~d}, J=7.2$ $\mathrm{Hz}, 1 \mathrm{H}), 7.33-7.26(\mathrm{~m}, 2 \mathrm{H}), 5.60(\mathrm{~s}, 1 \mathrm{H}), 4.31(\mathrm{t}, J=7.6 \mathrm{~Hz}, 2 \mathrm{H}), 3.49$ $(\mathrm{s}, 3 \mathrm{H}), 1.87-1.81(\mathrm{~m}, 2 \mathrm{H}), 1.38-1.29(\mathrm{~m}, 10 \mathrm{H}), 0.90(\mathrm{t}, J=7.2 \mathrm{~Hz}, 3$ $\mathrm{H})$.

${ }^{13} \mathrm{C}$ NMR $\left(100 \mathrm{MHz}\right.$, DMSO- $\left.d_{6}\right): \delta=149.2,142.0,135.7,123.1,122.1$, 120.4, 110.0, 100.7, 54.7, 44.4, 31.8, 29.7, 29.2, 29.1, 27.0, 22.6, 14.1 .

HRMS (ESI-TOF): $m / z$ [M + H] $]^{+}$calcd for $\mathrm{C}_{18} \mathrm{H}_{28} \mathrm{~N}_{2} \mathrm{O}_{2}$ : 305.2229; found: 305.2210 .

\section{1-Allyl-2-(dimethoxymethyl)-1H-benzimidazole (3k)}

Yield: $200 \mathrm{mg}$ (86\%); thick liquid.

IR (neat): 2933, 2831, 1620, 1515, 1331, 1206, $1064 \mathrm{~cm}^{-1}$.

${ }^{1} \mathrm{H} \mathrm{NMR}\left(400 \mathrm{MHz}, \mathrm{CDCl}_{3}\right): \delta=7.80-7.78(\mathrm{~m}, 1 \mathrm{H}), 7.36-7.24(\mathrm{~m}, 3 \mathrm{H})$, 6.00-5.90 (m, $1 \mathrm{H}), 5.57(\mathrm{~s}, 1 \mathrm{H}), 5.20(\mathrm{~d}, J=10 \mathrm{~Hz}, 1 \mathrm{H}), 5.10(\mathrm{~d}, J=$ $17.2 \mathrm{~Hz}, 1 \mathrm{H}), 4.96(\mathrm{~d}, J=5.6 \mathrm{~Hz}, 2 \mathrm{H}), 3.46(\mathrm{~s}, 6 \mathrm{H})$.

${ }^{13} \mathrm{C}$ NMR $\left(100 \mathrm{MHz}, \mathrm{CDCl}_{3}\right): \delta=149.2,142.0,135.6,132.4,123.3$, $122.2,120.3,117.3,110.3,100.7,54.8,46.6$.

HRMS (ESI-TOF): $m / z$ [M + H] $]^{+}$calcd for $\mathrm{C}_{13} \mathrm{H}_{16} \mathrm{~N}_{2} \mathrm{O}_{2}: 233.1290$; found: 233.1302 .

2-(Dimethoxymethyl)-1-(prop-2-ynyl)-1H-benzimidazole (31) Yield: $212 \mathrm{mg}$ (92\%); thick liquid.

IR (neat): 2933, 2821, 2311, 1694, 1516, 1461, 1336, $1067 \mathrm{~cm}^{-1}$.

${ }^{1} \mathrm{H} \mathrm{NMR}\left(400 \mathrm{MHz}, \mathrm{CDCl}_{3}\right): \delta=7.80(\mathrm{~d}, J=7.6 \mathrm{~Hz}, 1 \mathrm{H}), 7.55(\mathrm{~d}, J=8 \mathrm{~Hz}$, $1 \mathrm{H}), 7.39-7.28$ (m, $2 \mathrm{H}), 5.61$ (s, $1 \mathrm{H}), 5.16(\mathrm{~s}, 2 \mathrm{H}), 3.50$ (s, $6 \mathrm{H})$.

${ }^{13} \mathrm{C}$ NMR $\left(100 \mathrm{MHz}, \mathrm{CDCl}_{3}\right): \delta=148.8,141.8,135.1,123.7,122.7$, $120.4,110.1,100.8,77.1,73.1,55.0,33.7$.

HRMS (ESI-TOF): $m / z$ [M + H] $]^{+}$calcd for $\mathrm{C}_{13} \mathrm{H}_{14} \mathrm{~N}_{2} \mathrm{O}_{2}: 231.1134$; found: 231.1045.

(Z)-2-(Dimethoxymethyl)-1H-pyrido[2,3-b][1,4]diazepin-4(5H)one and $(Z)-4$--(Dimethoxymethyl)-1H-pyrido[3,2-b][1,4]diazepin-2(5H)-one (3m)

Yield: $176 \mathrm{mg}$ (75\%); yellowish solid; $\mathrm{mp} 140{ }^{\circ} \mathrm{C}$.

IR (neat): 3118, 2932, 1669, 1619, 1460, 1103, $1044 \mathrm{~cm}^{-1}$.

${ }^{1} \mathrm{H}$ NMR $\left(400 \mathrm{MHz}\right.$, DMSO- $\left.d_{6}\right): \delta=8.26-8.24(\mathrm{dd}, J=6.8,1.2 \mathrm{~Hz}, 1 \mathrm{H})$, $7.15(\mathrm{t}, J=7.2 \mathrm{~Hz}, 1 \mathrm{H}), 7.01-6.99(\mathrm{dd}, J=7.6,1.2 \mathrm{~Hz}, 1 \mathrm{H}), 6.35(\mathrm{~s}, 1 \mathrm{H})$, $6.18(\mathrm{~s}, 2 \mathrm{H}), 5.20(\mathrm{~s}, 1 \mathrm{H}), 3.34(\mathrm{~s}, 6 \mathrm{H})$.

${ }^{13} \mathrm{C}$ NMR $\left(100 \mathrm{MHz}\right.$, DMSO- $\left.d_{6}\right): \delta=160.0,158.0,142.9,142.5,117.9$, 113.8, 111.8, 103.1, 99.8, 53.9.

HRMS (ESI-TOF): $m / z[\mathrm{M}+\mathrm{H}]^{+}$calcd for $\mathrm{C}_{11} \mathrm{H}_{37} \mathrm{~N}_{3} \mathrm{O}_{3}: 236.1035$; found: 236.1023.

(Z)-2-(Dimethoxymethyl)benzo[b][1,4]thiazepin-4(5H)-one (3n) Yield: 70\%; thick liquid.

IR (neat): 3276, 2945, 1615, 1478, 1438, 1272, 1150, $1066 \mathrm{~cm}^{-1}$. $\left.{ }^{1} \mathrm{H} \mathrm{NMR} \mathrm{(400} \mathrm{MHz,} \mathrm{CDCl}_{3}\right): \delta=10.56(\mathrm{~s}, 1 \mathrm{H}), 7.28(\mathrm{~m}, 2 \mathrm{H}), 6.95(\mathrm{t}, J=$ $7.6 \mathrm{~Hz}, 2 \mathrm{H}), 4.88(\mathrm{~s}, 1 \mathrm{H}), 4.81(\mathrm{~s}, 1 \mathrm{H}), 3.74(\mathrm{~s}, 3 \mathrm{H}), 3.42(\mathrm{~s}, 3 \mathrm{H})$.

${ }^{13} \mathrm{C}$ NMR $\left(100 \mathrm{MHz}, \mathrm{CDCl}_{3}\right): \delta=170.8,148.1,135.4,129.0,127.3$, $122.7,117.3,115.9,84.9,79.8,55.8,50.9$.

HRMS (ESI-TOF): $m / z$ [M + H] $]^{+}$calcd for $\mathrm{C}_{12} \mathrm{H}_{13} \mathrm{NO}_{3} \mathrm{~S}: 252.0649$; found: 252.1009 . 


\section{Funding Information}

The authors gratefully acknowledge financial support from the Science and Engineering Research Board (SERB), Govt. of India (Project No EMR/2016/001537). The authors are also grateful to the Department of Science and Technology, Ministry of Science and Technology, India for providing the $400 \mathrm{MHz}$ NMR facility under the auspices of the DST-FIST programme (No SR/FST/CSI-263/2015).

\section{Supporting Information}

Supporting information for this article is available online at https://doi.org/10.1055/s-0040-1706391.

\section{References}

(1) (a) Demirayak, S.; Kayagil, I.; Yurttas, L. Eur. J. Med. Chem. 2011, 46, 411. (b) Kumar, K.; Awasthi, D.; Lee, S. Y.; Cummings, J. E.; Knudson, S. E.; Slayden, R. A.; Ojima, I. Bioorg. Med. Chem. 2013, 21, 3318. (c) Huang, S. T.; Hsei, I. J.; Chen, C. Bioorg. Med. Chem. 2006, 14, 6106. (d) Koci, J.; Klimesova, V.; Waisser, K.; Kaustova, J.; Dahse, H. M.; Mollmann, U. Bioorg. Med. Chem. Lett. 2002, 12, 3275.

(2) (a) Jiang, B.; Zhang, J.; Zheng, W.; Chen, L. J.; Yin, G. Q.; Wang, Y. X.; Li, X.; Sun, B.; Yang, H.-B. Chem. Eur. J. 2016, 22, 14664. (b) Datta, S.; Saha, M. L.; Stang, P. J. Acc. Chem. Res. 2018, 51, 2047. (c) Zhang, Y.; Zhou, Q.-F.; Huo, G.-F.; Yin, G.-Q.; Zhao, X.L.; Jiang, B.; Tan, H.; Li, X.; Yang, H.-B. Inorg. Chem. 2018, 57, 3516. (d) Gale, P. A.; Hiscock, J. R.; Lalaoui, N.; Light, M. E.; Wells, N. J.; Wenzel, M. Org. Biomol. Chem. 2012, 10, 5909. (e) AlMohammed, N. N.; Syahila, R.; Hussen, D.; Ali, T. H.; Alias, Y.; Abdullah, Z. RSC Adv. 2015, 5, 21865.

(3) Berrada, M.; Carriere, F.; Abboud, Y.; Abourriche, A.; Benamara, A.; Lajrhed, N.; Kabbaj, M.; Berrada, M. J. Mater. Chem. 2002, 12, 3551.

(4) (a) Shao, J.; Qiao, Y.; Lin, H.; Lin, H. J. Fluoresc. 2009, 19, 183. (b) Guo, Z.; Cao, R.; Li, X.; Yuan, D.; Bi, W.; Zhu, X.; Li, Y. Eur. J. Inorg. Chem. 2007, 742.

(5) Singh, N.; Jang, D. O. Org. Lett. 2007, 9, 1991.

(6) Li, L.; Hu, T.-L.; Li, J.-R.; Wang, D.-Z.; Zeng, Y.-F.; Bu, X.-H. CrystEngComm 2007, 9, 412.

(7) Roque, J. M.; Pandiyan, T.; Cruz, J.; Garcia-Ochoa, E. Corros. Sci. 2008, 50, 614.

(8) (a) Hussain, A.; AlAjmi, M. F.; Rehman, M. T.; Khan, A. A.; Shaikh, P. A.; Khan, R. A. Molecules 2018, 23, 1232. (b) Sahki, A. F.; Messaadia, L.; Merazig, H.; Chibani, A.; Bouraiou, A.; Bouacida, S. Chem. Sci. 2017, 129, 21. (c) Chkirate, K.; Karrouchi, K.; Dege, N.; Sebbar, N. K.; Ejjoummany, A.; Radi, S.; Adarsh, N. N.; Talbaoui, A.; Ferbinteanu, M.; Essassi, E. M.; Gracia, Y. New J. Chem. 2020, 44, 2210.

(9) (a) Gray, D. N. J. Heterocycl. Chem. 1970, 7, 947. (b) Hudkins, R. L. Heterocycles 1995, 41, 1045. (c) Mukhopadhyay, C.; Ghosh, S.; Butcher, R. J. ARKIVOC 2010, 75.

(10) (a) Majumdar, S.; Chakraborty, M.; Pramanik, N.; Maiti, D. K. RSC Adv. 2015, 5, 51012. (b) Maiti, D. K.; Halder, S.; Pandit, P.; Chatterjee, N.; Joarder, D. D.; Pramanik, N.; Saima, Y.; Patra, A.; Maiti, P. K. J. Org. Chem. 2009, 74, 8086. (c) Chari, M. A.; Shobha, D.; Sasaki, T. Tetrahedron Lett. 2011, 52, 5575. (d) Inamdar, S. M.; More, V. K.; Mandal, S. K. Tetrahedron Lett. 2013, 54, 579. (e) Sharghi, H.; Asemani, O. Synth. Commun. 2009, 39, 860. (f) Wen, X.; El Bakali, J.; Deprez-Poulain, R.; Deprez, B. Tetrahedron Lett. 2012, 53, 2440.

(11) (a) Peng, J.; Ye, M.; Zong, C.; Hu, F.; Feng, L.; Wang, X.; Wang, Y.; Chen, C. J. Org. Chem. 2011, 76, 716. (b) Ma, D.; Xie, S.; Xue, P.; Zhang, X.; Dong, J.; Jiang, Y. Angew. Chem. Int. Ed. 2009, 48, 4222. (c) Prasenjit, S.; Tamminana, R.; Nibadita, P.; Md, A. A.; Rajesh, P.; Tharmalingam, P. J. Org. Chem. 2009, 74, 8719. (d) Yang, D.; Fu, H.; Hu, L.; Jiang, Y.; Zhao, Y. J. Org. Chem. 2008, 73, 7841. (e) Evindar, G.; Batey, R. A. J. Org. Chem. 2006, 71, 1802. (f) Zou, B.; Yuan, Q.; Ma, D. Angew. Chem. Int. Ed. 2007, 119, 2652.

(12) (a) Chakraborty, A.; Majumdar, S.; Maiti, D. K. Tetrahedron Lett. 2016, 57, 3298. (b) Majumdar, S.; Chakraborty, A.; Bhattacharjee, S.; Debnath, S.; Maiti, D. K. Tetrahedron Lett. 2016, 57, 4595.

(13) (a) Li, Z.; Dong, J.; Chen, X.; Li, Q.; Zhou, Y.; Yin, S.-F. J. Org. Chem. 2015, 80, 9392. (b) Mayo, M. S.; Yu, X.; Zhou, X.; Feng, X.; Yamamoto, Y.; Bao, M. Org. Lett. 2014, 16, 764.

(14) Mamedov, V. A. RSC Adv. 2016, 6, 42132.

(15) (a) Chen, Y. L.; Hedberg, K.; Guarino, K.; Retsema, J. A.; Anderson, M.; Manousos, M.; Barrett, J.J. Antibiot. 1991, 44, 870. (b) Villa, P.; Arumugam, N.; Almansour, A. I.; Kumar, R. S.; Mahalingam, S. M.; Marrioka, K.; Thangamani, S. Bioorg. Med. Chem. Lett. 2019, 29, 729. (c) Hehir, S.; O'Donova, L.; Carty, M. P.; Aldabbagh, F. Tetrahedron 2008, 64, 4196. (d) Plater, M. J.; Barnes, P.; McDonald, L. K.; Wallace, S.; Archer, N.; Gelbrich, T.; Hortonc, P. N.; Hursthouse, M. B. Org. Biomol. Chem. 2009, 7, 1633.

(16) Davis, M. C.; Groshens, T. J. Synth. Commun. 2012, 2664.

(17) (a) Reddy, N. B.; Zyryanov, G. V.; Reddy, G. M.; Balakrishna, A.; Padmaja, A.; Padmavathi, V.; Reddy, C. S.; Garcia, J. R.; Sravya, G. J. Heterocycl. Chem. 2019, 56, 589. (b) Omprakash, K. L.; Reddy, K. G.; Pal, A. V. C.; Reddy, L. M. N. Indian J. Chem., Sect. A: Inorg., Bio-inorg., Phys., Theor. 1984, 23, 89.

(18) (a) Manna, S. K.; Mondal, S. K.; Ahmed, A.; Mondal, A.; Jana, A.; Iqbal, M.; Samanta, S.; Ray, J. K. RSC Adv. 2014, 4, 2474. (b) Manna, S. K.; Das, T.; Samanta, S. ChemistrySelect 2019, 4, 8781. (c) Ryabukhin, D. S.; Turdakov, A. N.; Soldatova, N. S.; Kompanets, M. O.; Ivanov, A. Y.; Boyarskaya, I. A. Beilstein J. Org. Chem. 2019, 15, 1962. (d) Evans, R. C.; Douglas, P.; Winscom, C. J. Coord. Chem. Rev. 2006, 250, 2093. (e) Sivasankari, G.; Boobalan, S.; Thamizhini, P.; Sharmila, A.; Kavitha, K.; Archana, S. J. Chem. Pharm. Res. 2018, $10,7$.

(19) (a) Kone, A.; Ouattara, M.; Zon, D.; Chany, A.-C.; Collet, S.; Sissouma, D.; Adjou, A. World J. Pharm. Res. 2018, 7, 1589. (b) Ooi, H. C.; Suschitzky, H. J. Chem. Soc., Perkin Trans. 1 1982, 2871.

(20) El-Ahwany, M. F.; Abd El-Azim, M. H. M. Curr. Sci. 2018, 115, 310.

(21) (a) Katritzky, A. R.; He, H-Y.; Long, Q.; Cui, X.; Level, J.; Wilcox, A. L. ARKIVOC 2000, (iii), 240. (b) Katritzky, A. R.; Rewcastle, G. W.; Fan, W. Q. J. Org. Chem. 1988, 53, 5685.

(22) Meng, L.; Wang, S. C.; Fettinger, J. C.; Kurth, M. J.; Tantillo, D. J. Eur. J. Org. Chem. 2009, 1578.

(23) (a) Sara, P. Angew. Chem. Int. Ed. 2019, 58, 14044. (b) Jiang, H.; Yang, J.; Tang, X.; Li, J.; Wu, W. J. Org. Chem. 2015, 80, 8763. (c) Cho, S. H.; Kim, J. Y.; Kwak, J.; Chang, S. Chem. Soc. Rev. 2011, 40, 5068. (d) Song, G.; Wang, F.; Li, X. Chem. Soc. Rev. 2012, 41, 3651 . 
(24) (a) Majumdar, S.; De, J.; Chakraborty, A.; Maiti, D. K. RSC Adv. 2014, 4, 24544. (b) Majumdar, S.; De, J.; Chakraborty, A.; Roy, D.; Maiti, D. K. RSC Adv. 2015, 5, 3200. (c) Majumdar, S.; Chakraborty, M.; Maiti, D. K.; Chowdhury, S.; Hossain, J. RSC Adv. 2014, 4, 16497.

(25) Das, R. N.; Sarma, K.; Pathak, M. G.; Goswami, A. Synlett 2010, 2908.

(26) Kumar, R.; Kumar, D.; Chakraborty, A. K. Synthesis 2007, 299.
(27) Azizian, J.; Karimi, A. R.; Kazemizadeh, Z.; Mohammadi, A. A.; Mohammadizadeh, M. R. Synthesis 2005, 1095.

(28) (a) Nasrollahzadeh, M.; Bayat, Y.; Habibi, D.; Moshaee, S. Tetrahedron Lett. 2009, 50, 4435.

(29) (a) Wilde, N.; Pelz, M.; Gebhardt, S. G.; Gläser, R. Green Chem. 2015, 17, 3378. (b) Zhang, T.; Zuo, Y.; Liu, M.; Song, C.; Guo, X. ACS Omega 2016, 1, 1034. 